\title{
FORMULASI STRATEGI PENGEMBANGAN KAWASAN UKM BERBASIS KOMODITAS UNGGULAN DI KABUPATEN INDRAGIRI HILIR RIAU
}

\author{
Nofrizal \\ Program Studi Manajemen Fakultas Ekonomi Universitas Lancang Kuning Pekanbaru \\ e-mail: nofrizalfe@unilak.ac.id
}

\begin{abstract}
Absract
The purpose of this research is helping district Indragiri Hilir Riau Province to arrange appropriate development strategy for Micro, Small and Medium Enterprises (MSMEs) of banana chips. The district has superior commodity area of banana fruit, but it has not yet well managed. The information used in this research has been collected from interviews and observation. This research used SWOT-24K analysis to create development strategy of MSMEs of banana chips. The analysis has a function to highlight business position that can be used to create and formulate development strategy. Result of this research showed that appropriate strategy development for the current situation is the turnaround strategy by using government fund and conducting national banana chips event/program.
\end{abstract}

Keywords: strategy, development, SWOT-24K

\begin{abstract}
Abstrak
Tujuan dari penelitian ini adalah untuk membantu kabupaten Indragiri Hilir Provinsi Riau menyusun strategi pengembangan kawasan UKM khususnya UKM keripik pisang yang tepat sehingga dapat meningkatkan pendapatan masyarakat setempat dengan cara menggali dan memanfaatkan komoditas unggulan daerah yang tidak dimiliki oleh daerah lain. Data penelitian diperoleh dengan menggunakan teknik wawancara dan observasi. Analisis penyusunan strategi pengembangan menggunakan Analisis SWOT-24K yang berfungsi memperjelas posisi bisnis yang dapat digunakan sebagai strategi bersaing yang bermanfaat untuk merumuskan strategi pengembangan. Hasil penelitian ini menunjukkan bahwa strategi pengembangan yang dapat digunakan adalah strategi bertahan dengan memanfaatkan pendanaan pemerintah dan membuat program berskala nasional tentang keripik pisang.
\end{abstract}

Kata kunci: strategi, pengembangan, SWOT-24K 


\section{PENDAHULUAN}

Pengembangan kawasan UKM suatu daerah merupakan salah satu cara yang dilakukan untuk meningkatkan ekonomi lokal. Perekonomian lokal berkaitan dengan produktivitas dari daerah tersebut, karena semakin tinggi produktivitas ekonomi sebuah daerah maka pendapatan yang dihasilkan menjadi tinggi, penghasilan per kapita meningkat, kesejahteran membaik, dan secara tidak langsung dapat memperluas pengembangan ekonomi daerah tersebut. Hubungan pengembangan kawasan dengan produktivias daerah berkaitan dengan kondisi daerah yang kondusif didukung dengan lingkungan usaha yang baik dari sektor-sektor industri dan sub-sektor yang ada di daerah tersebut dan dikelola dengan baik sehingga mampu menunjang produktivitas sebuah daerah. Jeni Wulandari (2012) menyatakan untuk meningkatkan kesejahteraan suatu daerah atau taraf ekonominya maka daerah tersebut harus bergantung pada produktivitas daerah tersebut. Oleh karena itu salah satu pendekatan untuk mengembangkan kawasan suatu daerah agar produktif adalah dengan melalui pengembangan perekonomian lokal dengan menggali komoditas unggulan di daerah tersebut.

Pemanfaatan komoditas unggulan lokal suatu daerah dapat dilakukan dengan cara menggali kearifan lokal. Walaupun memiliki keterbatasan untuk menggalinya seperti keterbatasan sumber daya alam, manusia, sosial, fisik, budaya, dan teknologi, namun tidak menutup kemungkinan bahwa daerah tersebut memiliki keunggulan komoditas yang belum digali dan dimanfaatkan secara maksimal yang tidak dimiliki oleh daerah lain. Salah satu caranya adalah dengan memanfaatan sumber daya alam yang bersumber dari pertanian dan perkebunan yang berlimpah tapi belum dimanfaatkan secara maksimal namun memiliki nilai ekonomi yang tinggi jika diolah dengan baik,
Kabupaten Indragiri Hilir (Inhil) merupakan daerah penghasil pertanian dan perkebunan dengan komoditas unggulan yaitu kelapa. Di samping itu Kabupaten Indragiri Hilir juga memiliki komoditas perkebunan yang lain dan cukup berlimpah yaitu pisang (Pisang Tanduk) yang masih belum dimanfaatkan secara maksimal oleh masyarakat setempat. Salah satu daerah yaitu kecamatan Batang Tuaka merupakan daerah penghasil komoditas buah pisang yang saat ini buahnya hanya dijual ke pusat kota kabupaten atau ke luar negeri (ekspor), padahal potensinya jika diolah dengan membuat diversifikasi produk dari buah pisang maka dapat meningkatkan pendapatan daerah tersebut. Saat ini untuk maksimalkan buah pisang tersebut sehingga memiliki nilai ekonomi masyarakat terbentur beberapa permasalahan di antaranya adalah kurangnya permodalan, kurangnya jiwa kewirausahaan, kesulitan dalam pemasaran, keterbatasan dan kualitas SDM yang rendah, kualitas teknologi pengelolahan yang kurang, dan peran pemerintah kabupaten yang belum optimal. Permasalahan ini mengakibatkan keinginan masyarakat untuk mengolah buah pisang menjadi produk siap saji dengan membuat produk diversifikasi menjadi rendah ditambah belum terbentuknya kawasan UKM keripik pisang di daerah tersebut. Oleh karena itu diperlukan tahapan penyusunan strategi pengembangan untuk memaksimalkan komoditas buah pisang di Kabupaten Indragiri Hilir.

Menurut beberapa ahli, strategi merupakan cara untuk mencapi tujuan perusahaan/organisasi (Wheelen, Hunger \& Hoffman, 2015; Suliyanto \& Wulandari, 2010) sedangkan manajemen strategi adalah seni atau ilmu dalam merumuskan, mengimplementasikan, dan mengevaluasi dari strategi yang telah dibuat (Porter, 2011). Strategi juga berkaitan dengan keunggulan bersaing (competitive advantage), keunggulan ini membuat perusahaan berbeda dari 
perusahaan lain (David \& F.R., 2016) sehingga perusahaan lain akan sulit untuk meniru keunggulan yang kita miliki (Dobbs, 2014) begitu juga dengan kebupaten Indragiti Hilir yang memiliki keunggulan di komuditas Perkebunan khususnya pisang yang dapat dijadikan keunggulan bersaing yang dapat membedakan dari pesaing dan merupakan factor kunci keberhasilan (Key Success factor) (Nofrizal, 2014) daerah berdasarkan bahan baku produk keripik pisang. Beberapa penelitian terdahulu tentang pengembangan keripik pisang telah dilakukan seperti di Bandar Lampung dengan hasil penelitian menunjukkan bahwa faktor penentu keberhasilan pengembangan usaha keripik pisang untuk meningkatkan pangsa pasar dan menjadi produk unggulan adalah: (1) kemampuan teknis, (2) keterampilan manajerial, (3) akses terhadap informasi, (4) proses produksi, dan (5) ketersediaan bahan baku (Apriyani, Hardjomidjojo, \& Kadarisman, 2014). Berdasarkan penjelasan latar belakang di atas maka dibuatlah rumusan permasalahan yaitu bagaimana strategi pengembangan wilayah UKM keripik pisang untuk menjadi kawasan yang produktif di Kabupaten Indragiri Hilir berbasis komuditas unggulan sehingga dapat meningkatkan nilai produk dari buah pisang.

\section{METODE PENELITIAN}

Penelitian ini dilakukan di kecamatan Batang Tuaka Kabupaten Indragiri Hilir Provinsi Riau. Metode penelitian yang digunakan mengunakan teknik deskriptif kualitatif yang bertujuan untuk mengambarkan sesuatu yang tengah berlangsung dengan melakukan analisis ekternal dan internal (Taufik \& Suprajang, 2016) dengan teknik pengembilan sampel secara purposive sampling yaitu pengambilan responden berdasarkan kriteria tertentu (Sugiyono, 2012).
EKSTERNAL (1,2)

- Lingkungan UMUM

- Industri

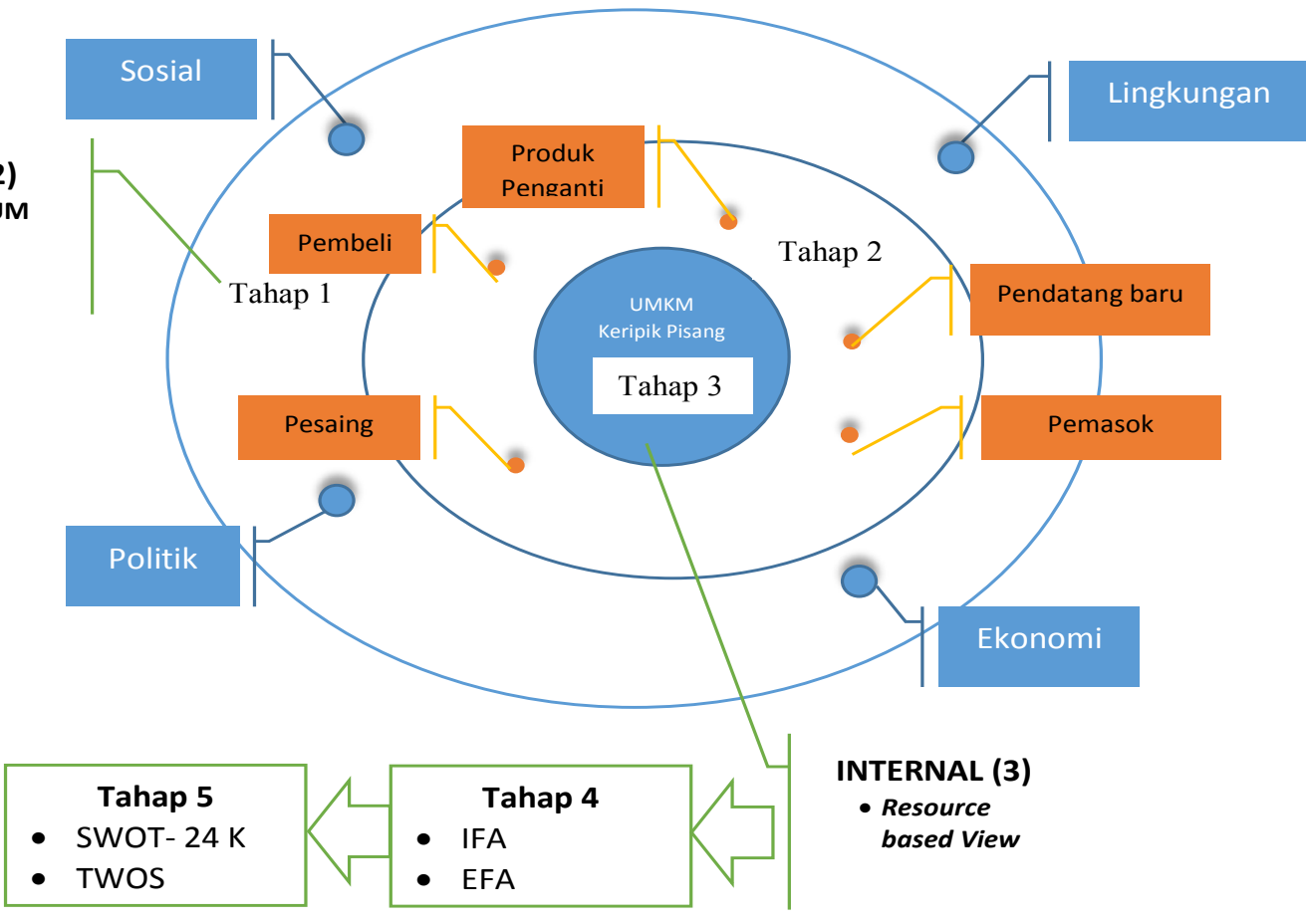

Gambar 1. Model Penelitian 
Selanjutnya metode pengumpulan data mengunakan teknik wawancara, observasi, dan literatur (Sugiyono, 2012). Pada analisis data menggunakan analisis SWOT24K dengan beberapa tahapan yaitu ke (1) Analisis lingkungan ekternal digunakan untuk mengetahui ancaman dan peluang yang akan dimasukkan ke dalam tabel Matrik EFE (Evaluasi Faktor Eksternal) (David \& F. R., 2016; Saputro, Hidayat \& Yulianto, 2016), tahapan ke (2) Analisis Lingkungan Internal digunakan untuk mengetahui kekuatan dan kelemahan yang kemudian akan dimasukkan ke dalam Matrik EFI (Evaluasi Faktor Internal) (Agus \& Supardi, 2012; Faruq \& Usman, 2016).

Setelah kedua tahapan di atas selesai selanjutnya adalah proses melakukan pembobotan dari masing-masing indikator yang dianggap memiliki pengaruh terhadap pengembangan UMKM keripik pisang (Wheelen, Hunger \& David, 2014). Selanjutnya tahapan ke (3) yaitu membuat matrik SWOT-24K (Muhammad, 2013), tahapan ke (4) penyusunan Matrik TWOS yang terdiri dari strategi SO,WO,WT,ST
(David \& F.R., 2016; Nofrizal, 2016) untuk menentukan strategi yang tepat untuk pengembangan kawasan UMKM keripik pisang Kabupaten Indragiri Hilir (Inhil).

\section{HASIL DAN PEMBAHASAN}

\section{Indentifikasi Lingkungan Eksternal}

\section{a. Lingkungan Umum}

Kabupaten Indragiri Hilir terdiri dari 20 kecamatan dengan jumlah dewan perwakilan rakyat daerah sebanyak 45 orang. Usaha pemerintah dalam menjamin kemajuan dan pengembangan UKM juga diprogramkan oleh Departemen Keuangan melalui SK Menteri Keuangan (Menkeu) No.316/KMK.016/1994. SK tersebut mewajibkan Badan Usaha Milik Negara (BUMN) untuk menyisihkan 1-5\% laba perusahaan bagi Pembinaan Usaha Kecil dan Koperasi (PUKK). Kewajiban BUMN untuk menyisihkan labanya $1-5 \%$ belum dikelola dan dilaksanakan dengan baik (Sukarwanto, 2016a) sedangkan ekonomi Kabupaten Indragiri Hilir merupakan daerah yang agraris (Sukarwanto, 2016c).

Tabel 1. Peranan PDRB Menurut Lapangan Usaha (Persen), 2011-2015

\begin{tabular}{|c|c|c|c|c|c|c|}
\hline & Lapangan Usaha/Industry & 2011 & 2012 & 2013 & 2014* & $2015^{* *}$ \\
\hline & (1) & (2) & (3) & (4) & (5) & (6) \\
\hline A & $\begin{array}{l}\text { Pertanian, Kehutanan, dan Perikanan/Agricu/ture, } \\
\text { Forestry and Fishing }\end{array}$ & 50.78 & 49.88 & 49.41 & 49.31 & 48.37 \\
\hline B & $\begin{array}{l}\text { Pertambangan dan Penggalian/Mining and } \\
\text { Quarrying }\end{array}$ & 0.44 & 0.46 & 0.79 & 0.74 & 0.63 \\
\hline c & Industri Pengolahan/Manufacturing & 24.56 & 25.06 & 25.41 & 24.52 & 24.81 \\
\hline D & Pengadaan Listrik dan Gas/Electricity and Gas & 0.04 & 0.04 & 0.03 & 0.03 & 0.04 \\
\hline E & $\begin{array}{l}\text { Pengadaan Air, Pengelolaan Sampah, Limbah dan } \\
\text { Daur Ulang/Water supply, Sewerage, Waste } \\
\text { Manogement and Remediation Activities }\end{array}$ & 0.02 & 0.02 & 0.02 & 0.01 & 0.01 \\
\hline $\mathrm{F}$ & Konstruksi/Construction & 4.84 & 5.03 & 5.24 & 5.11 & 5.35 \\
\hline G & $\begin{array}{l}\text { Perdagangan Besar dan Eceran; Reparasi Mobil dan } \\
\text { Sepeda Motor/Wholesale and Retail Trade; Repair } \\
\text { of Motor Vehicles and Motorcycles }\end{array}$ & 13.35 & 13.21 & 12.74 & 14.08 & 14.39 \\
\hline H & $\begin{array}{l}\text { Transportasi dan Pergudangan/Transportation and } \\
\text { Storage }\end{array}$ & 0.95 & 1.00 & 1.04 & 1.04 & 1.09 \\
\hline 1 & $\begin{array}{l}\text { Penyediaan Akomodasi dan Makan } \\
\text { Minum/Accommodotion and Food Service Activities }\end{array}$ & 0.42 & 0.43 & 0.44 & 0.43 & 0.43 \\
\hline
\end{tabular}


Sebagian besar penduduknya bekerja sebagai petani, sehingga pertanian terutama perkebunan merupakan lapangan usaha utama dan dominan dalam menggerakkan roda perekonomian masyarakat Kabupaten Indragiri Hilir.

Pertanian, kehutanan, dan perikanan merupakan penyumbang terbesar terhadap total PDRB Kabupaten Indragiri Hilir. Kontribusi dari pertanian, kehutanan, dan perikanan terhadap total PDRB kabupaten Indragiri Hilir pada tahun 2015 mencapai 48,37 persen. Perekonomian Indragiri Hilir pada tahun 2015 mengalami perlambatan dibandingkan tahun sebelumnya, dari 7,17 persen (2013) dan 6,86 persen (2014) menjadi 2,06 persen (2015). Perlambatan tersebut terutama terjadi pada lapangan usaha industri pengolahan, dari 11,04 persen (2013) dan 5,48 persen (2014) menjadi 3,17 persen (2015) (lihat tabel 1).

Lingkungan Indragiri Hilir merupakan kabupaten terluas di Provinsi Riau. Luas Kabupaten Indragiri Hilir mencapai 11.605,97 km2. Secara Geografis Indragiri Hilir terletak di bagian Selatan Provinsi Riau dengan letak antara 00 36' Lintang Utara dan 10 07' Lintang Selatan, dan antara 1040 10`Bujur Timur dan 1020 32’ Bujur Timur.
Sebagian besar luas wilayah Kabupaten Indragiri Hilir merupakan daerah dataran rendah dengan rata-rata ketinggian $<5$ meter dari permukaan laut yang mengakibatkan daerah ini menjadi daerah rawa-rawa beriklim tropis basah. Akan tetapi terdapat desa-desa yang merupakan daratan tinggi. Kabupaten ini juga berbatasan dengan Negara tetangga yaitu Malaysia dan Singapura. Lingkungan sosial penduduk Kabupaten Indragiri Hilir pada tahun 2015 berjumlah 703.734 jiwa, dengan jumlah penduduk laki-laki lebih banyak daripada penduduk perempuan (lihat tabel 2).

\section{b. Lingkungan Industri}

Pesaing merupakan faktor yang paling berpengaruh semenjak terbentuknya perdagangan bebas sehingga berimbas terhadap UKM di Indonesia. Dengan adanya perdagangan bebas yang masuk ke Indonesia, membuat pasar dalam negeri menjadi lesu karena masyarakat lebih memilih dan suka terhadap produk luar. Setiap tahun dampak perdagangan bebas terhadap UKM terus meningkat, hal ini disebabkan masih rendahnya daya saing produk asli dibandingkan dengan produk luar yang memiliki kualitas yang bagus.

Tabel 2. Indikator Kependudukan Indragiri Hilir, 2013-2015

\begin{tabular}{|c|c|c|c|}
\hline Uraian & 2013 & 2014 & 2015 \\
\hline (1) & (2) & (3) & (4) \\
\hline Jumlah Penduduk (jiwa) & 685.530 & 694.614 & 703.734 \\
\hline Kepadatan Penduduk (jiwa $/ \mathrm{km}^{2}$ ) & 59 & 60 & 61 \\
\hline Seks Rasio (\%) & 105,65 & 105,61 & 106 \\
\hline Jumlah Rumah Tangga & 167.723 & 169.946 & 172.120 \\
\hline Rata-rata ART (jiwa/ruta) & 4 & 4 & 4 \\
\hline \multicolumn{4}{|l|}{ Penduduk Menurut Kelompok Umur } \\
\hline 0-14 tahun & 205.275 & 205.965 & 206.641 \\
\hline $15-64$ tahun & 458.261 & 465.740 & 473.137 \\
\hline$>65$ tahun & 21.994 & 22.909 & 23.956 \\
\hline
\end{tabular}




\section{Analisis Lingkungan Internal}

Pendekatan Resource Base View yaitu pada Sumber Daya Fisik Bahan Mentah merupakan keunggulan yang dimiliki kabupaten Indragiri Hilir. Berdasarkan tabel 3 dapat diketahui bahwa dari 10 komoditas buah-buahan utama tahun 2015, buah pisang memiliki luas area (Ha) 168.69 yang paling luas dibandingkan buah yang lain dengan jumlah produksi (ton) 3859.49 (Sukarwanto, 2016a)
Sebagai kabupaten terluas di Provinsi Riau dengan luas mencapai 11.605,97 km2 dan berdekatan langsung dengan Malaysia dan Singapura, Kabupaten Indragiri Hilir memiliki kondisi tanah rawa-rawa yang sangat bagus untuk ditanam pisang dan secara geografis posisinya sangat strategis (Sukarwanto, 2016).

Jumlah penduduk Kabupaten Indragiri Hilir pada tahun 2015 berjumlah 703.734 jiwa. Penduduk Kabupaten Indragiri Hilir

Tabel 3. Sepuluh Komoditas Buah-buahan Utama Indragiri Hilir 2015

\begin{tabular}{|c|c|c|}
\hline Jenis Buah & $\begin{array}{c}\text { Luas Panen } \\
(\mathrm{Ha})\end{array}$ & $\begin{array}{l}\text { Produksi } \\
\text { (ton) }\end{array}$ \\
\hline (1) & (2) & (3) \\
\hline Pepaya & 7,45 & 129,24 \\
\hline Semangka & 139,00 & 151,80 \\
\hline Rambutan & 81,67 & 168,58 \\
\hline Manggis & 70,37 & 233,08 \\
\hline Sawo & 107,81 & 341,40 \\
\hline Nangka/Cempedak & 125,36 & 424,19 \\
\hline Mangga & 147,28 & 746,30 \\
\hline Jeruk & 121,22 & 1299,65 \\
\hline Pisang & 168,69 & 3859,49 \\
\hline Nanas & 127.78 & 9768,06 \\
\hline
\end{tabular}

Sumber: Indragiri Hilir Dalam Angka 2016

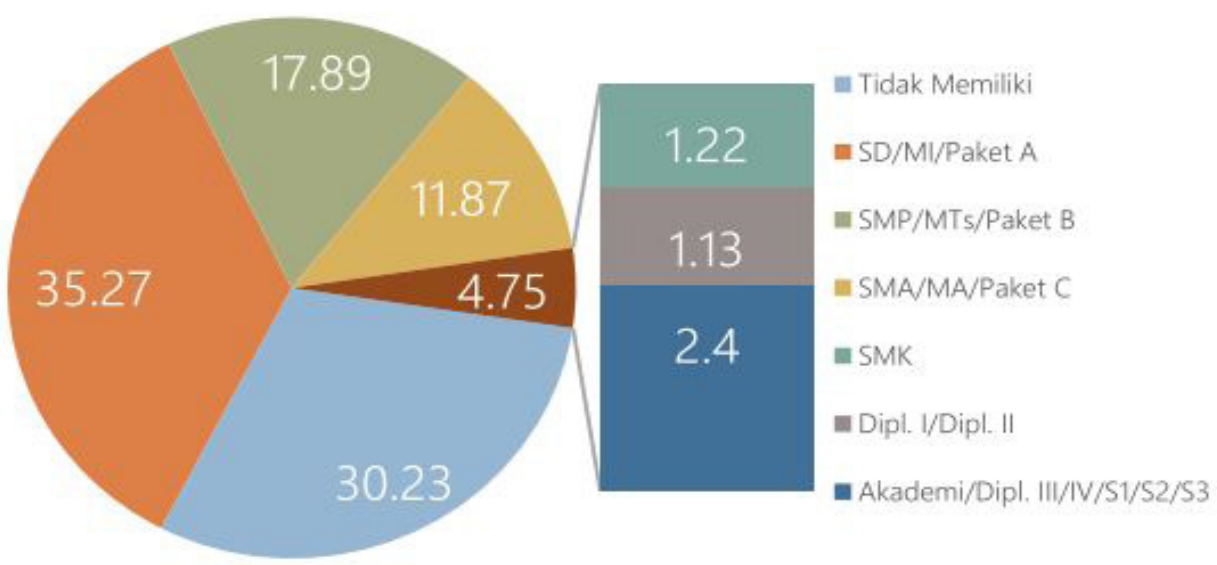

Sumber: Survei Sosial Ekonomi Nasional (Susenas) 2015

Gambar 2. Tingkat Pendidikan Indragiri Hilir 
didominasi oleh penduduk muda/dewasa. Jika kita lihat distribusi penduduk menurut umur menunjukkan bahwa 29,36 persen penduduk berusia muda (umur 0-14 tahun), 67,23 persen berusia 22.465 produktif (umur 15-64 tahun), dan hanya 3,4 persen yang berumur 65 tahun lebih. Berdasarkan angka mutlak dapat diperoleh angka ketergantungan (dependency ratio) sebesar 48,73. Angka tersebut menunjukkan bahwa setiap 100 penduduk usia produktif menanggung sekitar 48-49 orang penduduk usia tidak produktif. Untuk tingkat pendidikan hampir $35,27 \%$ penduduk Indragiri Hilir memiliki ijazah setingkat SD dan paling besar di antara kabupaten/kota di Riau. Kemudian yang tidak memiliki ijazah sekitar 30,23\%, atau nomor dua terbesar setelah Kepulauan Meranti (31,77\%). Sedangkan penduduk yang memiliki ijazah setingkat sarjana hanya 2,4\% atau paling rendah di Riau (lihat gambar 2) (Sukarwanto, 2016b).

Setelah diketahui data eksternal dan internal perusahaan dari kabupaten Indragiri Hilir tahapan berikutnya adalah tahapan ke 4 seperti pada gambar 1 yaitu menentukan nilai dari Eksternal Faktor Analisis (EFA) dan Internal Faktor Analisis (IFA). Sumber nilai penentuan Eksternal dan Internal Faktor berdasarkan data eksternal dan internal yang didapatkan melalui observasi dan kajian pustaka, setelah dilakukan tahapan penilaian dan pembobotan dan penentuan skala ditemukanfaktorpeluangeksternalyang paling berpengaruh adalah kebijakan pemerintah tentang UKM dengan nilai tertimbang 0.7284 sedangkan peluang terendah adalah faktor berdekatan dengan Malaysia dan Singapura. Berikutnya adalah faktor eksternal ancaman yang memiliki pengaruh yang cukup tinggi terhadap UKM keripik pisang diperoleh nilai tertimbang persaingan usaha sejenis di industri makan ringan 0.7336, sedangkan untuk internal faktor analisis nilai kekuatan yang paling berpengaruh adalah produksi pada tahun 2015 dan luas lahan pohon pisang dengan nilai 0.8613 dan 0.8076, namun di balik kekuatan yang dimiliki oleh kabupaten Indragiri Hilir terdapat kelemahan yaitu kurangya kemampuan keahlian dalam pengelolaan keripik pisang dengan nilai 1.1608 dan kurangya pengetahuan masyarakt tentang kewirausahaan dengan nilai 0.9364.

Setelah diketahui nilai tertimbang dari faktor internal dan eksternal UKM keripik pisang berikutnya adalah mengitung nilai selisih dari masing-masing lingkungan internal dan eksternal dengan cara mengurangkan nilai tertimbang peluang dan acaman dengan nilai perolehan -0.297. Sedang nilai tertimbang dari faktor internal kekuatan dan kelemahan yaitu -0.6351 dari nilai selisih yang didapatkan akan digunakan untuk menentukan posisi strategi dari UKM keripik pisang dengan menggunakan SWOT-24K. Dengan menggunakan ini kita akan dapat menentukan bagaimana strategi pengembangan kawasan UKM keripik pisang Kabupaten Indragiri Hilir, seperti tampak pada tabel 4.

\section{Matrik SWOT-24K}

Setelah diketahui nilai selisih dari faktor-faktor internal dan eksternal dari UKM keripik pisang maka tahapan berikutnya adalah menentukan posisi strategis dengan menggunakan SWOT-24K (lihat gambar 3).

Berdasarkan matrik SWOT-24K ditemukan bahwa posisi strategis UKM keripik pisang berada di posisi strategi penyehatan. David \& F. R. (2016) menyarankan perusahaan sebaiknya fokus pada meralat kelemahan internal dan diversifikasi terkait. Strategi defensif termasuk pelepasan, pengurangan, likuidasi, dan diversifikasi terkait. Berdasarkan peryataan tersebut maka diketahui bahwa UKM keripik pisang masih perlu banyak memperbaiki dari internal faktor yang masih lemah seperti masih lemahnya peran pemerintah dan tingkat pengetahuan dan keahlian masyarakat dalam mengelola 
Tabel 4. Eksternal \& Internal Faktor Analisis (EFA, IFA)

\begin{tabular}{|c|c|c|c|c|}
\hline No & Faktor-Faktor Eksternal & Bobot & Ranting & $\begin{array}{l}\text { Nilai } \\
\text { Tertimbang }\end{array}$ \\
\hline & Peluang & & & \\
\hline 1 & Kebijakan Pemerintah tentang UKM & 0.1821 & 4 & 0.7284 \\
\hline 2 & Kewajiban BUMN untuk memberikan Laba 1-5\% & 0.1612 & 4 & 0.6448 \\
\hline 3 & Jenis Pekerjaan Petani & 0.0911 & 3 & 0.2733 \\
\hline 4 & Berdekatan dengan Malaysia dan Singapura & 0.0676 & 2 & 0.1352 \\
\hline 5 & Animo masyarakat yang cukup tinggi terhadap jajanan keripik. & 0.0521 & 3 & 0.1563 \\
\hline 6 & Kondisi keamanan kawasan yang terjamin untuk mengelola usaha. & 0.0701 & 2 & 0.1402 \\
\hline \multirow[t]{3}{*}{7} & $\begin{array}{l}\text { Jalur tranfortasi sudah mendukung hingga ke desa efek dari pro- } \\
\text { gram desa mandiri Kab, Inhil }\end{array}$ & 0.0892 & 3 & 0.2676 \\
\hline & SUB TOTAL & & & 2.3458 \\
\hline & Ancaman & & & \\
\hline 1 & Efek dari pasar bebas 2015 & 0.1803 & 4 & 0.7212 \\
\hline 2 & Mudahnya produk-produk luar negeri masuk & 0.1687 & 3 & 0.5061 \\
\hline 3 & Persaingan usaha sejenis di industri makan ringan & 0.1834 & 4 & 0.7336 \\
\hline 4 & Ada produk penganti seperti kerupuk amplang & 0.0976 & 4 & 0.3904 \\
\hline \multirow[t]{3}{*}{5} & $\begin{array}{l}\text { Kurang adanya perhatian khusus dari pemerintah daerah terhadap } \\
\text { UKM }\end{array}$ & 0.0723 & 4 & 0.2892 \\
\hline & SUB TOTAL & & & 2.6405 \\
\hline & Selisih Nilai Tertimbang Kekuatan dan Kelemahan & & & -0.2947 \\
\hline \multirow[t]{2}{*}{ No } & Faktor-Faktor Internal & Bobot & Ranting & $\begin{array}{c}\text { Nilai } \\
\text { Tertimbang }\end{array}$ \\
\hline & Kekuatan & & & \\
\hline 1 & $\begin{array}{l}\text { Untuk bahan baku mentah lahan panen buah pisang } 168.69 \text { (Ha) } \\
\text { dibandingkan buah lain }\end{array}$ & 0.2019 & 4 & 0.8076 \\
\hline 2 & Produksi pada tahun 2015 buah pisang 3859.49 (ton) & 0.2871 & 3 & 0.8613 \\
\hline 3 & Lokasi geografis tanah rawa-rawa bagus untuk tanaman pisang & 0.1012 & 2 & 0.2024 \\
\hline 4 & $\begin{array}{l}\text { Posisi kabupaten strategis berhadapan langsung dengan Malaysia } \\
\text { dan Singapura }\end{array}$ & 0.1601 & 1 & 0.1601 \\
\hline 5 & Akses bahan buku mudah & 0.1809 & 2 & 0.3618 \\
\hline \multirow[t]{3}{*}{6} & $\begin{array}{l}\text { Jumlah penduduk yang cukup banyak sebensar } 703.734 \text { jiwa dima- } \\
\text { na lebih didominasi laki-laki }\end{array}$ & 0.0901 & 2 & 0.1802 \\
\hline & SUB TOTAL & & & 2.5734 \\
\hline & Kelemahan & & & \\
\hline 1 & Kurangnya kemampuan keahlian dalam pengelolaan keripik pisang & 0.2902 & 4 & 1.1608 \\
\hline 2 & Permodalaan masih rendah dan terbatas & 0.1202 & 3 & 0.3606 \\
\hline 3 & Pengetahuan masyarakat tentang kewirausahan masih rendah & 0.2341 & 4 & 0.9364 \\
\hline 4 & Kesulitan dalam pemasaran produk & 0.1901 & 3 & 0.5703 \\
\hline \multirow[t]{3}{*}{5} & $\begin{array}{l}\text { Masih rendahnya tingkat pendidikan mayoritas lulusan sekolah } \\
\text { dasar }\end{array}$ & 0.0902 & 2 & 0.1804 \\
\hline & SUB TOTAL & & & 3.2085 \\
\hline & Selisih Nilai Tertimbang Peluang dan Ancaman & & & -0.6351 \\
\hline
\end{tabular}

Sumber: data olahan, 2017 


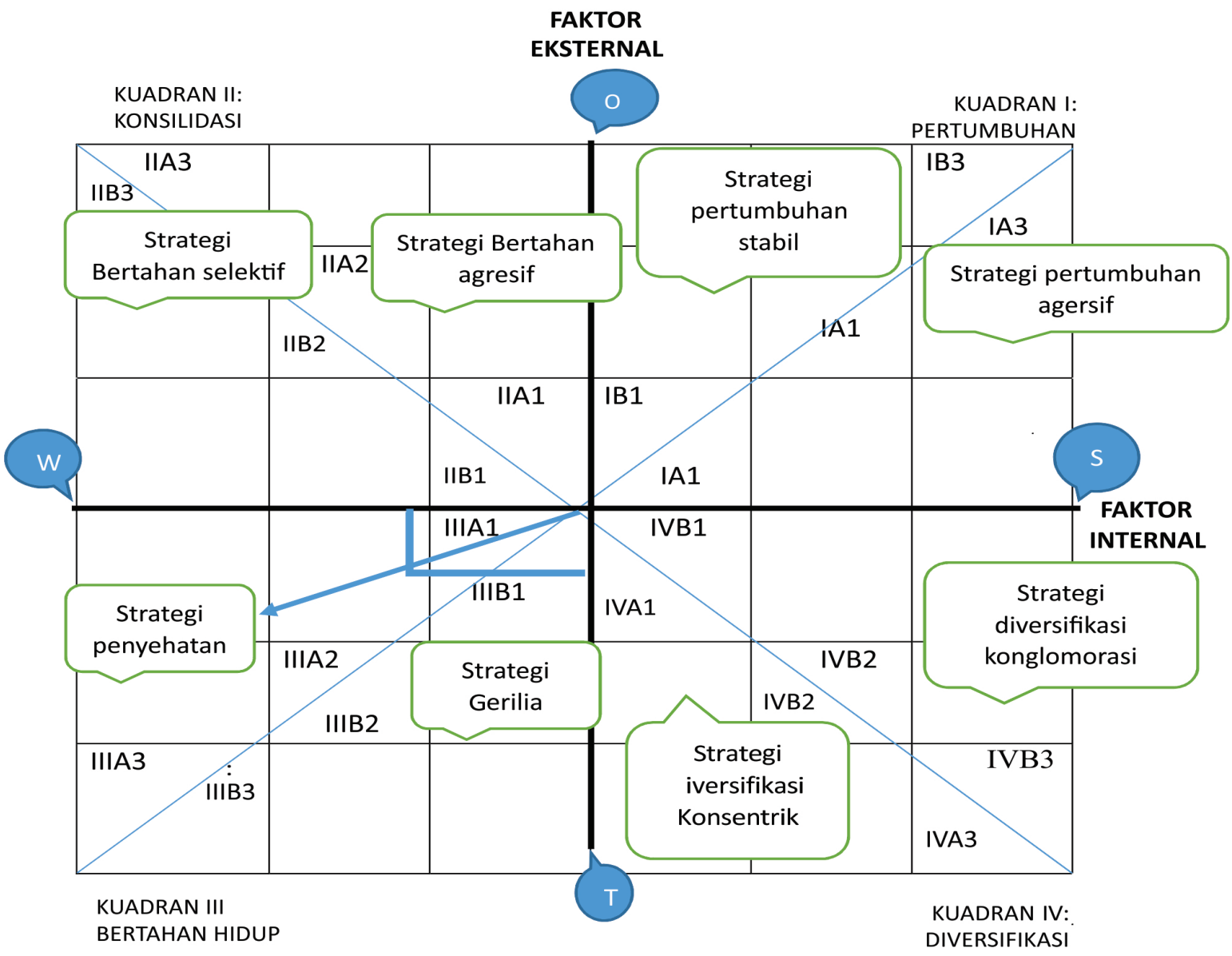

Gambar 3. Matrik SWOT-24K UKM keripik Pisang Kabupaten Inhil

Sumber: data olahan, 2017

buah pisang masih rendah, ditambah sumber daya manusia yang masih didominasi berpendidikan sekolah dasar (SD). Faktor eksernal yang mengancam juga memiliki pengaruh yang besar terhadapa UKM keripik pisang seperti faktor mudahnya masuk produk-produk dari luar negeri yaitu Malaysia dan pesaing di industri makanan ringan seperti keripik tempe, kerupuk amplang dan lain-lain.

\section{Matrik TWOS}

Tahapan ini adalah tahapan terakhir dalam perumusan strategi pengembangan kawasan UKM keripik pisang kabupaten Indragiri Hilir. Metode ini mengunakan teknik formulasi dari berbagai faktor-faktor internal dan eksternal sehingga muncul beberapa strategi SO (Kekuatan dan Peluang), WO
(Kelemahan dan Peluang), ST (Kekuatan dan Ancaman), WT (Kelemahan dan Ancaman) seperti tampak pada tabel 5 .

Berdasarkan tabel 5 ditemukan beberapa strategi yang bisa digunakan untuk mengembangkan kawasan UKM keripik pisang kabupaten Inhil yaitu:

- Strategi SO: Memanfaatkan dana pemerintah dan BUMN untuk membuat kawasan UKM keripik pisang, menjadikan keripik pisang produk unggulan Inhil sebagai oleh-oleh, membuat sentral penjualan keripik pisang di pelabuhan, terminal, dan pusat keramaian, dan membangun kawasan UKM keripik pisang di Kecamatan Batang Tuaka. 


\section{Tabel 5. Matrik TWOS UKM Keripik Pisang Kabupaten Inhil}

\begin{tabular}{|c|c|c|}
\hline $\begin{array}{r}\text { Faktor } \\
\text { Internal }\end{array}$ & $\begin{array}{l}\text { Kekuatan } \\
\text { Untuk bahan baku mentah } \\
\text { Produksi pada tahun } 2015 \text { buah pi- } \\
\text { sang } \\
\text { Lokasi geografis } \\
\text { Posisi kabupaten strategis } \\
\text { Akses bahan buku mudah } \\
\text { Jumlah penduduk }\end{array}$ & $\begin{array}{l}\text { Kelemahan } \\
\text { Kurangnya kemampuan keahlian } \\
\text { dalam pengelolaan } \\
\text { Permodalaan } \\
\text { Pengetahuan masyarakat } \\
\text { Masih rendahnya tingkat pendidikan }\end{array}$ \\
\hline $\begin{array}{l}\text { Peluang } \\
\text { Kebijakan Pemerintah } \\
\text { Kewajiban BUMN } \\
\text { Jenis Pekerjaan } \\
\text { Berdekatan dengan Malaysia } \\
\text { dan Singapura } \\
\text { Animo masyarakat } \\
\text { Kondisi keamanan kawasan } \\
\text { Jalur tranfortasi }\end{array}$ & $\begin{array}{l}\text { Memanfaatkan dana Pemerintah dan } \\
\text { BUMN Membuat Kawasan UKM } \\
\text { Keripik Pisang (K1,K2,P1,P2) } \\
\text { Menjadikan Keripik P isang Menjadi } \\
\text { produk unggulan Inhil sebagai oleh- } \\
\text { oleh (K3,K4,K5,P4,P7) } \\
\text { Membuat sentral Penjualan Keripik } \\
\text { Pisang di Pelabuhan terminal, dan } \\
\text { pusat keramian (K6,K3,P7,P4) } \\
\text { Membangun kawasan UKM Keripik } \\
\text { Pisang di Kec. Batang Tuaka } \\
\text { (P7,P6,P4,K3,K1,K2) }\end{array}$ & $\begin{array}{l}\text { Strategi WO (Kelemahan\&Peluang) } \\
\text { Memperbiki manajemen pengelolaan } \\
\text { dana dari Pemerintah dari BUMN } \\
\text { (L2, P1,P2) } \\
\text { Keaktifan Dinas-dinas untuk menga- } \\
\text { dakan pelatihan dan pembimbingan } \\
\text { (L1,L3,L4,P1,P5,P7) } \\
\text { Membuat program-Program tentang } \\
\text { keripik pisang (L3,L1, P1,P4,P7) } \\
\text { Selalu memberikan program ped- } \\
\text { ampingan dari program-program } \\
\text { (L1,P1,P2) }\end{array}$ \\
\hline $\begin{array}{l}\text { Ancaman } \\
\text { Efek dari pasar bebas } \\
\text { Mudahnya produk-produk luar } \\
\text { negeri } \\
\text { Persaingan usaha sejenis } \\
\text { Ada produk penganti } \\
\text { Kurang adanya perhatian khu- } \\
\text { sus dari pemerintah }\end{array}$ & $\begin{array}{l}\text { Strategi ST (Kekuatan\&Ancaman) } \\
\text { Membuat pelatihan diversifasi } \\
\text { produk membuat keripik pisang } \\
\text { (K1,K5,A3,A4) } \\
\text { Membuat peraturan yang menggun- } \\
\text { tungkan UKM keripik Pisang (K2,K5, } \\
\text { A5,A1) }\end{array}$ & $\begin{array}{l}\text { Meningkatkan perhatian pemerintah } \\
\text { dengan dana bergulir (A3,A5,L2, L4) } \\
\text { Meningkatkan pengetahuan masyara- } \\
\text { kat dengan program-program UKM } \\
(\mathrm{L} 1, \mathrm{~L} 4, \mathrm{~A} 5, \mathrm{~A} 4, \mathrm{~A} 2)\end{array}$ \\
\hline
\end{tabular}

Sumber: data olahan, 2017

- Strategi WO: Memperbaiki manajemen pengelolaan dana dari pemerintah dan BUMN, keaktifan dinas-dinas untuk mengadakan pelatihan dan pembimbingan, membuat programprogram tentang keripik pisang, dan selalu memberikan program pendampingan.

- Strategi ST: Membuat pelatihan diversifasi produk keripik pisang, dan membuat peraturan yang mendukung majunya UKM keripik pisang.

○ Strategi WT: Meningkatkan perhatian pemerintah dengan dana bergulir dan meningkatkan pengetahuan masyarakat dengan program-program UKM.

Hasil penelitian menunjukkan strategi yang dapat digunakan oleh UKM keripik pisang di kabupaten Indragiri Hilir yaitu strategi penyehatan melaui bekerja sama dengan pemerintah dan perusahan untuk memperbaiki segala kelemahan yang dimiliki dengan menggunakan kekuatan yang dimiliki. Hasil penelitian ini juga mendukung pada penelitian sebelumnya tentang strategi pengembangan seperti penelitian yang dilakukan oleh Pele, Lamusa, \& Tangkesalu (2013) yang menyatakan bahwa strategi alternatif yang tepat untuk UKM "Pundi Mas" adalah strategi SO. Strategi SO merupakan strategi yang dapat digunakan UKM "Pundi Mas" dalam menciptakan strategi yang menggunakan kekuatan untuk memanfaatkan peluang yang ada. 


\section{KESIMPULAN}

Kabupaten Indragiri Hilir memiliki peluang untuk membuat kawasan yang fokus kepada UKM keripik pisang seperti sama halnya dengan kelapa yang sudah terkenal sejak lama. Berdasarkan hasil formulasi strategi dengan mengunakan IFA, EFA, SWOT-24K, dan TWOS ditemukan banyak sekali peluang-peluang yang masih belum dimaksimalkan secara baik padahal hal tersebut berlimpah di Kabupaten Indragiri Hilir, bahkan buah pisang tersebut dapat menjadi keunggulan daerah yang bisa dibanggakan di tingkat nasional sebagai ciri khas kedua setelah kelapa. Setelah dilakukanya penelitian ini peneliti berharapa kepada pemerintah Kabupaten Inhil untuk memberikan perhatian khusus kepada masyarakat untuk mengembangkan komoditas buah pisang dengan membuat program-program yang berkitan dengan pengelolaan keripik pisang dengan memanfaatkan dana dari pemerintah dan perusahaan, sedangkan untuk penetapan harga jual ditentukan oleh pasar itu sendiri (pasar persaingan sempurna) bukan ditentukan oleh perusahaan-perusahaan atau pemerintah jadi kemungkinan untuk maju dan berkembang sangatlah besar peluangnya.

\section{REFERENSI}

Agus, Prayitno, Suprapti Supardi, E. D. N. 2012. Analisis Strategi Pengembangan Agribisnis Komoditas Sayuran Unggulan di Asosiasi Aspakusa Makmur Kabupaten Boyolali. Mediagro, 8(2), 8-20.

Apriyani, M., Hardjomidjojo, H., \& Kadarisman, D. 2014. Prospek Pengembangan Usaha Keripik Pisang di Bandarlampung. Manajemen IKM, 9(1), 89-95.

David, F. R. \& F. R. (2016). Strategic Management: A Competitive Advantage Approach, Concepts and Cases. 15th edition. England: Pearson-Prentice Hall.

Dobbs, M. E. 2014. Guidelines for applying Porter's five forces framework: a set of industry analysis templates. Competitiveness Review, 24(1), 32-45. https://doi.org/http://dx.doi. org/10.1108/CR-06-2013-0059

Faruq, M. A., \& Usman, I. 2016. Penyusunan Strategi Bisnis dan Strategi Operasi Usaha Kecil dan Menengah pada Perusahaan Konveksi Scissors di Surabaya. Jurnal Manajemen Teori dan Terapan Journal of Theory and Applied Management, 7(3).

Jeni, Wulandari. 2012. Strategi Pengembangan Kawasan Industri Kecil Berbasis Komoditas Unggulan (Studi Kasus Kawasan Sentra Industri Keripik Kota Bandar Lampung). Jurnal Ilmiah Administrasi Publik dan Pembangunan, 3(1), 421-432.

Muhammad, Suwarsono. 2013. Manajemen Strategik Konsep dan Alat Analisis. Yogyakarta: UPP STIM YKPN.

Nofrizal. 2014. Analisis Strategi Bersaing Gudang Digital Yogyakarta dalam Memperluas Pasar. Jurnal Ilmiah Ekonomi dan Bisnis, 11(2), 481-501.

Nofrizal. 2016. Analisis Strategi Pemasaran BMT Al Ittihad Rumbai dalam Memperluas Pasar. Pekbis Jurnal, 8(3), 228-240. http://ejournal. unri.ac.id/index.php/JPEB/article/ view $/ 3637 / 3537$

Pele, A. T., Lamusa, A., \& Tangkesalu, D. 2013. Strategi Pengembangan Keripik Singkong Balado pada UKM Pundi Mas di Kota Palu. Agrotekbis 1(5), 457-463.

Porter, M. E. 2011. Competitive advantage of nations: creating and sustaining superior performance. Simon and Schuster. 
Saputro, A. S., Hidayat, K., \& Yulianto, E. 2016. Perencanaan Strategi Pemasaran Paket Data Kampus dalam Persaingan di Bidang Paket Data Internet (Studi Kasus pada PT. Telkomsel Cabang Malang). Jurnal Administrasi Bisnis, 36(1), 163-169.

Sugiyono, P. 2012. Metode Penelitian Kuantitatif, Kualitatif dan $R \& D$. Bandung: Alfabeta.

Sukarwanto, S. 2016. Statistik Daerah Kecamatan Batang Tuaka. Kabupaten Indragiri Hilir.

Sukarwanto, S. 2016a. Produk Domestik Regional Bruto Kabupaten Indragiri Hilir Menurut Lapangan Usaha. Kabupaten Indragiri Hilir.

Sukarwanto, S. 2016b. Statistik Daerah Kabupaten Indragiri Hilir 2016. Kabupaten Indragiri Hilir.

Sukarwanto, S.2016c. StatistikKesejahteraan Rakyat. Kabupaten Indragiri Hilir.
Suliyanto, Siti Zulaikha Wulandari, W. N. 2010. Competitive Strategy Model for Purbalingga Batik. Economic Journal of Emerging Markets, 2(2), 170-185.

Taufik, M. I., \& Suprajang, S. E. 2016. Analisis Threats, Opportunity, Weakness, Strengths (TOWS) sebagai Landasan dalam Menentukan Strategi Pemasaran pada PR. Semanggimas Agung Boyolangu Kabupaten Tulungagung. Riset Mahasiswa Ekonomi (RITMIK), 2(1).

Wheelen, Thomas L, J. David Hunger, Alan N Hoffman, C. E. B. 2015. Strategic Management and Business Policy: Globalization, Innovation and Sustainability: Global Edition. England: Pearson Higher Ed.

Wheelen, Thomas L, J. David Hunger. 2016. Strategic Management and Business Policy Toward Global Sustainability.13th Edition. England: Pearson 